\title{
Ethnobotanical Significance of Picrorhiza Kurroa (Kutki), a Threatened Species
}

\author{
Isha Kumari $^{1}$, Hemlata Kaurav ${ }^{2}$, Gitika Chaudhary ${ }^{3}$ \\ ${ }^{1}$ Junior Research Executive, ${ }^{2}$ Research Associate, ${ }^{3}$ H.O.D. - Research and Development, \\ Shuddhi Ayurveda, Jeena Sikho Lifecare Pvt. Ltd. Zirakpur 140603, Punjab, India \\ Corresponding Author: Gitika Chaudhary
}

\begin{abstract}
Herbal plants have been used in the health maintenance customs since the origin of mankind. The herbal products have negligible adverse impacts on the consumer health because they have suitable and beneficial physiological actions on the living systems. Traditional systems of medication primarily use plants in their practices. The market demand of these plant based products has been increased over the past few years. Picrorhiza kurroa Royle ex Benth is one of the most established herbal plants with extraordinary medicinal properties. It belongs to Scrophulariaceae family and commonly called as Kutki. Picrorhiza kurroa is also called as bitter drug due to presence of Kutkin, principle phytochemical constituent of this medicinal plant. It is used in Ayurveda and folk system for treating liver related disorders and used as a remedy for jaundice, malaria, cut, wounds, snake bites etc. Its main therapeutic properties are antimalarial, antidiabetic, hepatoprotective, anticancer, anti-mutagenic, anti-inflammatory, immunomodulatory etc. The aim of present review is to provide information related to phytochemistry, traditional uses in Ayurveda and folk medicinal system and therapeutic properties of Picrorhiza kurroa.
\end{abstract}

Keywords: Kutki, Kutkin, Rasapanchak, Hepatoprotective, Antimalarial

\section{INTRODUCTION}

Mother nature has been fulfilling our requirements since ancient times. It has gifted us a vast variety of important medicinal plants which are being used primarily in traditional medication systems.
The chemical constituents of these plants are served as chemical entities for synthetic drugs. This is the reason why plant kingdom is entitled with "the treasure house of potential drugs ${ }^{[1-7]}$. These medicinal plays also play a vital role in cosmetic and nutraceutical industry. Herbal nutraceuticals have a great impact on maintaining the health and longevity of life ${ }^{[8,9]}$. These medicinal plants are the rich source of secondary metabolites like flavonoids, saponins, alkaloids, triterpenes etc. which have a definite, compatible and suitable physiological actions on the human body this is the reason why the drugs derived from herbal plants have negligible side effects ${ }^{[10-12]}$. The WHO estimation on the utilization herbal drugs revealed that $80 \%$ of the world population relies mainly on herbal medicines ${ }^{[13-17]}$. The continent Asia has a very history of using herbals for the treatment of numerous chronic as well as infectious human diseases ${ }^{[18]}$. India being the botanical garden of the world and listed among the World biodiversity centers, uses more than 45000 different plant species for health maintenance ${ }^{[19,20]}$. The traditional medication systems (Ayurveda and folk) of India greatly promote the use of medicinal plants [21]. China has been using herbal plants in their day to day life for many years. Japan, Hong Kong, Korea and Singapore are known primary importers of Traditional Chinese Medicine which are taking almost $66 \%$ share of China's total herbal drug export ${ }^{[22-24]}$. As per the historical reports, various different plant 
species of plants were used by Amerindians ${ }^{[25]}$. It is believed that many American plant species were introduced by the Spanish and the Portuguese to many parts of the world [26]. Balkan Peninsula, the most important biodiversity center of Europe, comprises of 6340 different vascular plant species ${ }^{[27]}$. The plant diversity of Turkey comprises of 10,500 different plant species among which $30 \%$ are the native plants of Turkey ${ }^{[28,29]}$. In African continent it as a very common practice of using traditional medicines ${ }^{[30]}$. A large proportion of Nigerian population use traditional medicines in their daily routine $^{[31]}$. The ancient practices of using medicinal plants are gaining popularity and being continually adapted by many populations ${ }^{[32]}$. There are so many important medicinal plants around the world which are of great significance in traditional medication systems and one such significant plant is Picrorhiza kurroa Royle ex Benth (figure 1). It is a member of Scrophulariaceae family and commonly called as Kutki in hindi and many other languages. It is a native plant of western Himalayas. The word Picrorhiza is made up of two words "picross", Greek word which indicates a meaning bitter while the word "rhiza" indicates roots. The Punjabi name of the plant "Karu", indicates the same meaning as that of "rhiza" [33]. Scrophulariaceae family consists of 200 genera and 3000 species which are mainly found in the northern temperate regions of the world. Popular garden plants (including tiny alpines) and aesthetically important plants such as Penstemon, Mimulus and Calceolaria are some members of this family ${ }^{[34]}$. It is an esteemed medicinal plant in traditional medication systems especially in Ayurveda. In ancient Ayurvedic literature by Jivek, Charak and Vagbhatt Picrorhiza kurroa is mentioned as an important remedy. Also this medicinal plant is listed as an official drug in Indian Pharmacopoeia [35]. In Ayurveda and other traditional systems, it is used against variety of diseases such as liver and respiratory tract problems, dyspepsia, chronic diarrhea, scorpion sting, fever and dyspepsia, dropsy, asthma, leprosy, arthritis, stomachic troubles, wounds, cuts etc. ${ }^{[36,37]}$. It has diverse phytochemistry composed of iridoids, acetophenones and cucurbitacins, apocynin. Kutkin is the major active principle phytochemical constituent present in this plant which is used in number of herbal formulations due to associated extraordinary therapeutic properties ${ }^{[38,39]}$. The root of Picrorhiza kurroa are therapeutically important. They act as laxative in small doses and cathartic in large doses. They are also used against gastrointestinal and urinary disorders, leukoderma, snake bite, scorpion sting and inflammation ${ }^{[40,41]}$. It is a plant of great pharmacological and therapeutic significance. It is associated with properties like antimalarial, antidiabetic, hepatoprotective, anticancer, antimutagenic, anti-inflammatory, immunomodulatory etc. Picrorhiza kurroa is listed under highly threatened plant species thus for its conservation conventional and biotechnological approaches has been initiated so that maximum benefit can be derived from this wonder herb in future also ${ }^{[42]}$. Vernacular names and taxonomic classification of Picrorhiza kurroa is given in table 1 and 2 respectively.

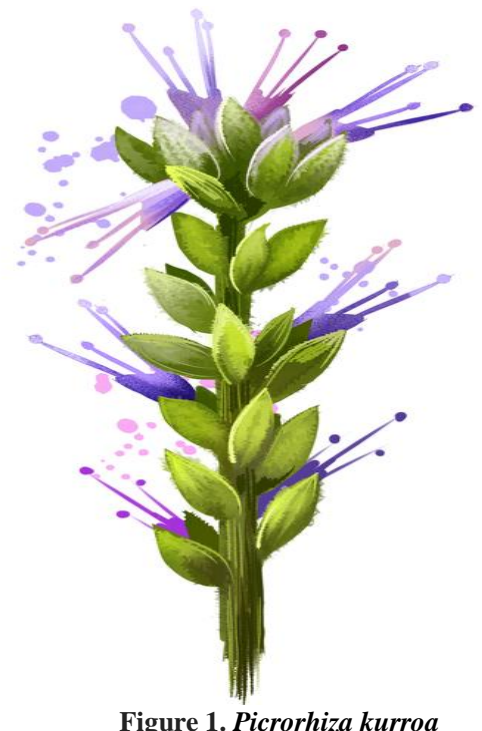

Figure 1. Picrorhiza kurroa 
Table 1: Vernacular Names of Picrorhiza kurroa

\begin{tabular}{|l|l|}
\hline English & Hellebore \\
\hline Sanskrit & Kutki \\
\hline Hindi & $\begin{array}{l}\text { Tikta, Tiktarohini, Kaurohini, Kavi, Sutiktaka, } \\
\text { Kauka, Rohini }\end{array}$ \\
\hline Assamese & Katki, Kutki \\
\hline Gujrati & Kadu, Katu \\
\hline Kannada & Katuka rohini, \\
\hline Malyalam & Katuka rohini, Kaduk rohini \\
\hline Marathi & Kutki, Kalikutki \\
\hline Oriya & Katuki \\
\hline Punjabi & Karru, Kaur \\
\hline Tamil & Katuka rohini, Katuku rohini, Kadugurohini \\
\hline Telugu & Karukarohini \\
\hline Urdu & Kutki \\
\hline
\end{tabular}

Table 2: Taxonomy of Picrorhiza kurroa ${ }^{[43]}$

\begin{tabular}{|l|l|}
\hline Taxonomic Rank & Taxon \\
\hline Kingdom & Plantae \\
\hline Division & Dicotiledonae \\
\hline Class & Asteride \\
\hline Order & Scrophulariales \\
\hline Family & Scrophulariaceae \\
\hline Genus & Picrorhiza \\
\hline Species & kurroa \\
\hline Common Name & Kutki
\end{tabular}

\section{Morphological Description of Picrorhiza kurroa $^{[44-46]}$}

It is a small perennial herb which attains height up to $10-20 \mathrm{~cm}$. A small leafy weak creeping stem is present which is erect at flowering. This plant contains 6-10 inches long hard roots which are wrinkled and grayish to brown in color. Rhizomes are $2.5-12.0 \mathrm{~cm}$ long, $0.3-1.0 \mathrm{~cm}$ thick, cylindrical which are curved in irregular manner with the branching and rooting at the jointed nodes. The rhizomes are externally greyish-brown in appearance. Numerous aerenchymas are present in leaf, aerial stem and rhizome. The basal alternate leaves present in this plant are 5 to $15 \mathrm{~cm}$ in length. Leaves are oval in shape and are acuminate, serrate, stalked, winged, oblanceolate or narrowly spathulate and are coarsely toothed. Two kind of glandular hair are present over the leaves. Picrorhiza kurroa has white or pale purple colored bisexual flowers which are present on long terminal spikes. Calyx has equal 5 parts with 4-5 lobbed corolla. Lobes are actinomorphic. Slightly didynamous stamens which are 4 in number are inserted on corolla tube. Capitate stigma is present. Picrorhiza kurroa has acute ovoid and swollen fruits/capsules which are $6-10 \mathrm{~mm}$ in size, tapered at top, split up into 4 valves.
Numerous pale brown seeds are present in this plant. Seeds ae almost 1 x $0.8 \mathrm{~mm}$ in size and ellipsoid in shape. A very thick and transparent seed coat is present over the seeds.

\section{Geographical Distribution of Picrorhiza kurroa Kutki}

It is an indigenous plant of western Himalayan at 3000-5000 m of elevation ${ }^{[47]}$. Western Himalayan range includes Jammu and Kashmir, Himachal Pradesh and Uttarakhand. In Kashmir, it is mainly found in Gurez, Lolab, Karna, Sindh and Lidder Valleys. In Uttarakhand it is found in areas of Badrinath, Kedarnath and Chamba. In Himachal Pradesh it is wildly found in hilly districts such as Chamba, Pangi, Kullu, Shimla, Kinnaur and Lahaul valleys ${ }^{[48]}$. $P$. kurroa grows well in moist, sandy clay loamin textured soils which have high in organic matter present in them ${ }^{[49]}$. It is found in Pakistan, Nepal, Bhutan, China ${ }^{[50]}$.

\section{Phytochemistry of Picrorhiza kurroa}

The study reports on its phytochemistry revealed that it contains complex mixture of phytochemicals. It mainly consists of iridoids, acetophenones and cucurbitacins. The active phytochemical constituent present in Picrorhiza kurroa is kutkin (a bitter phytochemical constituent) which is made up of picrosides and kutkosides. The major picrosides present in kutkin are picroside I and II which are ideally iridoid glycosides. The kutkoside and picroside are present in fixed proportion of 1:2. Kutkins are associated with heaptoprotective activity. Picroside III, V and pikuroside, 6-feruloylcatalpol, minecoside are present as a minor iridoid glycosides constituent. Triterpenes are included in cucurbitacins. Major cucurbitacins are cucurbitacin B, D and R. Stuppner et al., discovered six novel cucurbitacin form this plant. Curcubitacins are associated with cytotoxic and antitumorous activities. Other constituents present in this plant are, minecoside, picein, 4-hydroxy-3- methoxy acetophenone, 
apocyanin, vanillic acid, cinnamis veronicoside acid, D-mannitol, kutkiol, kutkisterol and a ketone and phenolic glycosides like picein and androsin.
Apocynin (catechol) is anti-inflammatory in nature and prevents oxidative burst of neutrophil. It is believed that androsin exhibits anti-asthmatic properties ${ }^{[51-58]}$.
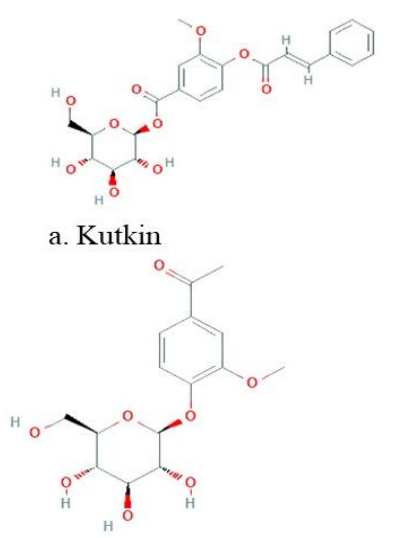

d. Androsin

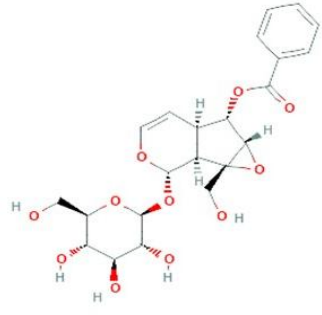

b. Veronicoside

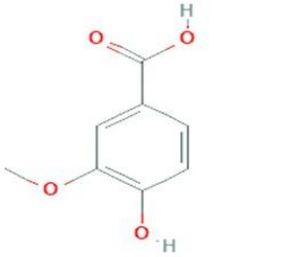

e. Vanillic acid

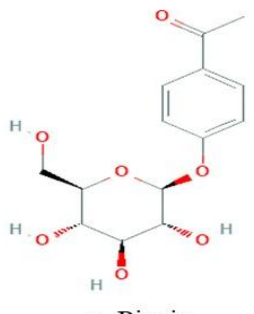

c. Picein

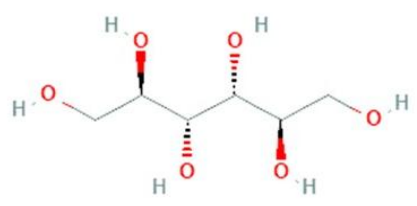

f. D-mannitol

Figure 2. Chemical Structures of some of phytochemical constituents of Picrorhiza kurroa

\section{Traditional and Modern View}

\section{a. Ayurvedic View of Picrorhiza kurroa}

Ayurveda mainly focus on maintaining the equilibrium of our three body components/doshas of the body i.e. kapha (water\&earth), pitta (fire) and vata (space \&air) ${ }^{[59,60]}$. Picrorhiza kurroa is a well-known medicinal plant which has a very rich history of its use in Ayurvedic medicine system. Its medicinal value has been mentioned in many Ayurvedic literatures like Nighantu, Caraka Samhita, Susruta Samhita, Astang Samgraha. It is useful in maintaining the kapha, Pitta dosha of the body. It is mainly used for treating digestion related problems, billow fever, urinary discharge, hiccup, blood troubles, burning sensations, leucoderma, and jaundice ${ }^{[61-64]}$. Rasapanchak of Picrorhiza kurroa is given in table 3 .

Table 3. Rasapanchak of Picrorhiza kurroa as per Ayurveda

\begin{tabular}{|l|l|}
\hline Sanskrit/English & Sanskrit/English \\
\hline Virya/Potency & Sheeta/Cold \\
\hline Vipak/Metabolic property & Katu/Pungent \\
\hline Guna/Physical property & Laghu/Light, Ruksha/Dry \\
\hline Rasa/Taste & Tikat/Bitter \\
\hline
\end{tabular}

Properties and Uses of Picrorhiza kurroa as per Ayurveda ${ }^{[65,66]}$
Paachan sansthan: It acts as an appetizer and digestion enhancer when used in low dose. Also acts as an anthelminthic. It is used to treat anorexia and weak metabolism, liver related disorders and jaundice. It cleans the bowel. It treats constipation and bloating when used in high amounts. It stimulates the secretion of digestive juices. It softens the hard stool.

Rakatwah sansthan: It is used for heart related problems. It helps in regulating blood pressure. Also acts as a blood purifier. It reduces edema.

Shwasan sansthan: It has ant mucolytic properties. It is used to treat cough and asthma.

Mootrawah sansthan: It is antidiabetic agent.

Prajannan sansthan: It works on problems related to lactogenesis.

Twacha: It is useful in treating skin disorders.

Taapkram: It has antipyretic properties. It is used to treat malarial fever.

Saatmikaran: It provides nourishment when taken in small dose. It scrapes the endotoxins and fats out from the body. It is used to treat malnutrition and obesity. 


\section{Ayurvedic Formulations of Picrorhiza kurroa}

Arogyavardhini gutika, Tiktaka ghrita, Laghumanjishthadi kwatha, Sarvajvarahara lauha are some important Ayurvedic formulations of Picrorhiza kurroa $^{[67]}$.

- Arogyavardhini gutika is pitta shamak which works on secretion of bile. It improves the digestion and functioning of liver ${ }^{[68]}$.

- Tiktaka ghrita is a polyherbal formulation made up many medicinal plants like Trichosanthes dioica, Azadirachta indica, Picrorhiza kurroa, Alhagi pseudalhagi, Fumaria indica, and Gentiana kurroo, Cyperus rotundus, Andrographis paniculata, Holarrhena antidysenterica, and Piper longum. This formulation is effectively used against skin diseases, wounds, inflammation, piles, sinus, etc. ${ }^{[69]}$.

- Laghumanjishthadi kwatha is another important polyherbal formulation made up of Manjishtha, Triphla, Kutki, Vacha, Daruhaidra, Haridra, Gudduchi and Nimba which is used as ablood purifier and kaphaghna and kledaghna ${ }^{[70]}$.

- Sarvajvarahara lauha is an efficient Ayurvedic iron formulation which is used to treat iron deficiency anemia. It significantly increases the $\mathrm{Hb}$ regeneration ${ }^{[71]}$.

\section{Folk View}

There are so many different cultures around the world which use variety of plants in their own way to treat several diseases. Medicinal plants are of great importance in folk cultures and they are associated with rich ethnobotanical uses. Ethnobotany is the term related with the association of human cultures with the plants. Plants are used for so many purposes like for food, shelter, medicine, divination etc. There are some strong cultural beliefs associated with many plants due to which they are worshiped ${ }^{[72]}$. Picrorhiza kurru L, Kutki is one such plant which is used for health maintenance purpose by many folk cultures. For instance, it is used as a traditional remedy for fever by Bhotiya tribal communities of Niti valley in Central Himalaya ${ }^{[73]}$. The Gaddi and Gujjar tribes of Himachal Pradesh, use kutki roots as an appetite enhancer. They use the kutki decoction along with ajwain as a remedy in skin infection to purify blood ${ }^{[74]}$. The rhizome powder of Picrorhiza kurru $L$ kutki is used traditionally in Hamirpur district of Himachal Pradesh as a cure to liver related problems and jaundice ${ }^{[75]}$. The roots, rhoizome and flowers of kutki are used to treat fever and are used as blood purifier in North region of Himachal Pradesh especially in Lahaul and Spiti ${ }^{[76]}$. In Pangi Himachal Pradesh, people use rhizomes in the treatment of cold and cough where as they use decoction as a blood purifier and dried powder as a pain killer [77]. In Kashmir, the tribal people of Kupwara district use kutki rhizomes and roots as a tonic, laxative and stomachic when their powder form is boiled in water [78]. In Gurez region of Kashmir, the root powder is used traditionally for treating liver related problems like jaundice ${ }^{[79]}$. In Grahwal Himalayas, this plant is traditionally used to cure chronic dysentery, asthma, dyspepsia, hepatic derangement, and jaundice. It also used as diuretic antipyretic, muscle relaxant, antistress, antiinflammatory, analgesic, and CNS depressant ${ }^{[80]}$. In West Sikkim, the root paste of kutki is used traditionally to cure cuts, injuries and wounds [81]. The traditional practitioners, Jhankri, Bijuwa and Phedangma in Darjeeling Himalaya use rhizome of kutki against fever, cold and snake bite ${ }^{[82,83]}$. In Rawain valley, Uttarkashi people use roots of this plant in treating fever, typhoid, jaundice, stomache [84]. In Gharwal Himalayas, root powder mixture of Cassia anguistifolia Vahl, Picrorhiza kurru L, Trachyspermum ammi is used traditionally as a remedy for itching. People also used paste of sarson oil and boiled fruits of Kutki externally against itching ${ }^{[85]}$. The dried roots are traditionally used to treat malarial fever chronic fever, and problems related to respiration in Rangit 
Valley, South Sikkim ${ }^{[86]}$. In some areas of Sikkim, people use extract of fresh leaves to treat jaundice and they use root decoction as an appetizer [87]. In Uttarakhand, the decoction of dried roots of kutki with black pepper and honey is used traditionally for the treatment of fever, dysentry, jaundice, stomache ${ }^{[88,89]}$. In Devikund, the fever is treated by root extract of Picrorhiza kurru ${ }^{[90]}$. People of Arawali Hills, use rhizome powder of this plant to kill pinworms ${ }^{[91]}$. In Asi Ganga sub-basin, Western Himalaya, people administer roots extract or powder orally to treat fever, jaundice, pain, and dysentery ${ }^{[92]}$. The tribal people of Sikkim and Darjeeling use Picrorhiza kurru rhizome to treat diabetes ${ }^{[93]}$. In North Sikkim people use rhizome either its decoction or powder to treat heart related issues, urinary disorders, piles, malarial fever, body ache. They use it as a tonic in anemia and constipation ${ }^{[94]}$. In folk medicine practices of some regions of Sikkim, roots and rhizomes of Picrorhiza kurru are being used to treat fever, cough and asthma ${ }^{[95]}$. In Ladhak, roots of kutki are used against stomache ${ }^{[96]}$. The Sherpas of Helambu, Central Nepal use kutki roots against fever. They also used roots as an appetizer and a bitter tonic [97]. The traditional healers of limboo tribe in southwest of khangchendzonga biosphere reserve, Sikkim use dried rhizome of kutki against variety of diseases like fever, dysentery, cough, cold, dysentery, headache, throat pain, stomache ${ }^{[98]}$. The traditional heals of Parvathi Valley, use roots of this plant as a remedy to abdominal pains. They use leaf drops against nose bleeding ${ }^{[99]}$. In Tungnath - Chopta region, kutki is used to treat fever ${ }^{[100]}$. People use extract of dried root of Picrorhiza kurru in the treatment of fever, dyspepsia in Darjeeling district of West Bengal ${ }^{[101]}$.

\section{Modern View of Picrorhiza kurroa}

The global and domestic markets of herbal drugs are growing increasingly nowadays because people have inclined more towards herbal products ${ }^{[102]}$. But due to great market demand, these natural products are getting adulterated or contaminated directly or indirectly in order to derive maximum benefit [103]. Adulteration and contamination directly affects the quality of herbal drugs ${ }^{[104]}$. Species adulteration in the global herbal drug industry has been observed for a long time ${ }^{[105,106]}$. For instance, Picrorhiza kurroa is being adulterated with many other plants such as Gentiana kurroo Royle (trayamana), Plectranthus amboinicus, Helleborus niger L., Neopicrorhiza scrophulariiflora, Actaea spicata L., Cimicifuga foetida L., Coptis teeta Wall., Coscinium fenestratum, Sorbus cashmiriana Hedl., Delphinium zalil, Delphinium saniculifolium Boiss., Ficus heterophylla L.f., Thalictrum foliolosum DC., Gentianella moorcroftiana, Latoris cashmiriana (Royle ex Benth.). These plants are sold out in the market samples of the Picrorhiza kurroa [107,108]. These adulterated herbal products have adverse effects on the consumer health ${ }^{[109]}$. These alterations should be detected by proper standardization and quality analysis techniques. WHO guidelines for standardized of herbal products must be implied to ensure the quality, safety and efficacy of drugs herbal medicines ${ }^{[110]}$.

\section{Therapeutic Uses of Picrorhiza kurroa Anti-microbial}

Antimicrobial potential of Picrorhiza kurroa was evaluated by Usman et al. They conducted an in-vitro study on bacterial starins i.e Bacillus subtilis and Staphylococcus aureus gram positive bacteria and Pseudomonas aeruginosa and Escherichia coli gram negative bacteria and Aspergillus niger, Candida albicans and Malasseiza furfur fungal strains. It was observed that ethanolic extract of this plant showed efficient action against all the used strains of microbes which suggests its use an anti-microbial ${ }^{[111]}$. Antimicrobial activity of Picrorhiza kurroa was also investigated by Sharma et al. It was observed that methanol extract showed more potent actions against bacterial strain 
(E. coli, B. subtilis, S. aureus) than antibacterial drug ciprofloxacin and aqueous extract was found to be more effective against fungal strain (A. niger, C. albicans) than Fluoconazole which is a standard antifungal drug ${ }^{[12]}$.

\section{Anti-asthmatic}

As per the report of Sehgal et al., invivo and in-vitro study, Picrorhiza kurroa is associated with anti-asthmatic properties. They used guinea pig models for the study. For in-vivo study histamine was used to induce broncho-constriction in the models. It was revealed from the study that ethanolic extract of the roots showed protective actions. Whereas for in-vitro study same extract was studied on isolated guinea pig ileum. Protective actions of ethanolic extract were observed which demonstrated that Picrorhiza kurroa is associated with antiasthmatic properties ${ }^{[113]}$.

\section{Anticancer}

Rajeshkumar et al., conducted an invivo study on BALB/c mice models for the evaluation of anti-cancer activity of Picrorhiza kurroa. Sarcoma was induced by 20- methylcholanthrene (20- MC) in models and papilloma formation was initiated

7,12- dimethylbenz[a]anthracene (DMBA) in the models. The oral administration of picroliv (100 and $200 \mathrm{mg} / \mathrm{kg}$, p.o) showed inhibitory actions against 20- MC and DMBA by decreasing sarcoma and papilloma. This study suggested that picroliv is a potent anti-cancer agent ${ }^{[114]}$.

\section{Anti-oxidant}

Kalaivani et al., conducted an invitro study to evaluate the anti-oxidant and free radical scavenging potential of Picrorhiza kurroa. It was observed that ethanolic extract of this plant showed significant anti-oxidant properties due to the presence of flavonoid and phenolic compounds ${ }^{[115]}$.

\section{Anti-mutagenic}

As per the reported study conducted by Zaberi et al., hydroalcoholic extract of Picrorhiza kurroa is associated with antimutagenic actions. It was found that hydroalcoholic extract exhibited inhibitory actions against Salmonella typhimurium MTCC 1251 and MTCC 1252 strains by direct acting mutagen of sodium azide ${ }^{[116]}$.

\section{Immunomodulatory}

As per the Hussain et al., in-vivo study report Picrorhiza kurroa is associated with immunomodulatory activities. The study was carried out on immunosuppressed mice models. Cyclophasphamide was induced in the models for immunosuppression. The study concluded that the alcoholic plant extract is significantly works on enhancement on immunostimulant activities ${ }^{[117]}$.

\section{Anti-inflammatory}

An in-vivo study carried out by Kumar et al., on rat models to evaluate the Anti-inflammatory activities of Picrorhiza kurroa, suggested that this plant is a potent source of anti-inflammatory drug. In the study models were administered with carrageenan for inducing paw edema and implanted with cotton pellet for inducing granuloma formation. Rhizome extract of Picrorhiza kurroa in a dose dependent manner effectively worked on the inhibition of carrageenan-induced paw edema and cotton pellet-induced granuloma formation. It was also observed that there was reduction in levels of inflammatory cytokines (TNF- $\alpha$, IL-1 $\beta$, IL-6) which is accompanied with increase in antiinflammatory cytokine (IL-10) level in the serum and peritoneal macrophages ${ }^{[118]}$.

\section{Hepatoprotective}

Hepatoprotective activity of Picrorhiza kurroa was investigated by Shetty et al., on male Wistar rat models. Models were fed with $30 \%$ high fat diet for 2 weeks for inducing non-alcoholic fatty 
liver disease (NAFLD). The administration of hydroalcoholic extract for 4 weeks at the dosage of $200 \mathrm{mg} / \mathrm{kg}$ and $400 \mathrm{mg} / \mathrm{kg}$ b.i.d., p.o. showed potent hepatoprotective actions by restoring all the changes in the liver induced in the liver ${ }^{[119]}$.

\section{Anti-diabetic}

Hussaain et al., conducted an in-vivo study on rat models to investigate the antidiabetic potential of Picrorhiza kurroa. The models were administered with streptozotocin nicotinamide to induce diabetes mellitus. The oral administration of standardized aqueous extract effectively helped in restoring all the changes induced by streptozotocin nicotinamide which suggests Picrorhiza kurroa use as an antidiabetic agent ${ }^{[120]}$. Some reported pharmacological studies are summarized in table 4.

\section{CONCLUSION}

Medicinal herbs are the significant segment of healthcare systems. They are being used to treat various ailments. Medicinal plants are the promising source of discoveries of new drugs. Picrorhiza kurroa is a well-known perennial medicinal plant which is used in Ayurveda for as a remedy for liver and digestion related problems. It is used as main ingredient in many Ayurvedic polyherbal formulations. It commonly used plant in folk systems around the world for curing malaria, jaundice, typhoid, stomache, itching etc. It is used as a blood purifier in some folk practices. The active principle constituent of this plant exhibits many therapeutic properties. His plant is associated with therapeutic properties like antimalarial, antidiabetic, hepatoprotective, anticancer, anti-mutagenic, antiinflammatory, immunomodulatory etc. The phytochemical constituents of this unique plant can be served as chemical entities for the new drugs in future.

\section{ACKNOWLEDGEMENT}

Authors are very thankful to the Department of Research and Development of Jeena Sikho Pvt. Ltd. Zirakpur Punjab for giving us opportunity to explore the ethnobotanical aspect of this medicinal plant.

\section{Conflict of Interest: None}

\section{Source of Funding: None}

\section{REFERENCES}

1. Samuelsson G. Drugs of natural origin: a textbook of pharmacognosy, 5th Swedish Pharmaceutical Press. Stockholm, Sweden. 2004.

2. Abu-Shanab, B., Adwan, G. M., AbuSafiya, D., Jarrar, N., \& Adwan, K. (2005). Antibacterial activities of some plant extracts utilized in popular medicine in Palestine. Turkish Journal of Biology, 28(24), 99-102.

3. Gurib-Fakim A. Medicinal plants: traditions of yesterday and drugs of tomorrow. Molecular aspects of Medicine. $2006 \mathrm{Feb}$ 1;27(1):1-93.

4. Choudhary S, Kaurav H, Chaudhary G. Kasani beej (Cichorium intybus): Ayurvedic View, Folk View, Phytochemistry and Modern Therapeutic Uses. International Journal for Research in Applied Sciences and Biotechnology. 2021 Mar 25;8(2):11425.

5. Nair, R., Kalariya, T., \& Chanda, S. (2005). Antibacterial activity of some selected Indian medicinal flora. Turkish Journal of biology, 29(1), 41-47.

6. Vickers A, Zollman C. Herbal medicine. Bmj. 1999 Oct 16;319(7216):1050-3.

7. Hill, A. F. (1937). Economic botany. A textbook of useful plants and plant products. Economic botany. A textbook of useful plants and plant products.

8. Banjare L, Kashyap P. Formulation and Evaluation of Herbal Multipurpose Cream. 2014;5(1):5-8.

9. Chauhan B, Kumar G, Kalam N, Ansari SH. Current concepts and prospects of herbal nutraceutical: a review. Journal of advanced pharmaceutical technology \& research. 2013 Jan;4(1):4.

10. Edeoga HO, Okwu DE, Mbaebie BO. Phytochemical constituents of some Nigerian medicinal plants. African journal of biotechnology. 2005 Aug 19;4(7):685-8. 
11. Mann, J.1978. Secondary Metabolism. Oxford University press, London, pp. 154.

12. Cragg GM, Newman DJ. Natural product drug discovery in the next millennium. Pharmaceutical biology. 2001 Jan 1;39(sup1):8-17.

13. Foster, B. C., Arnason, J. T., \& Briggs, C. J. (2005). Natural health products and drug disposition. Annu. Rev. Pharmacol. Toxicol., 45, 203-226.

14. Akinyemi, B. (2000). Recent concept in plaque formation. Journal of Clinical Pathology, 30, 13-16.

15. Calixto, J. B. (2005). Twenty-five years of research on medicinal plants in Latin America: a personal view. Journal of ethnopharmacology, 100(1-2), 131-134.

16. Sahito, S. R., Memon, M. A., Kazi, T. G., Kazi, G. H., Jakhrani, M. A., Haque, Q. U., \& Shar, G. Q. (2003). Evaluation of mineral contents in medicinal plant Azadirachta indica (Neem). Journal-Chemical Society of Pakistan, 25(2), 139-143.

17. Joseph B, Raj SJ. Pharmacognostic and phytochemical properties of Aloe vera linn an overview. Int J Pharm Sci Rev Res. 2010 Jan 1;4(2):106-.

18. Duraipandiyan V, Ayyanar M, Ignacimuthu S. Antimicrobial activity of some ethnomedicinal plants used by Paliyar tribe from Tamil Nadu, India. BMC complementary and alternative medicine. 2006 Dec;6(1):1-7.

19. Abd El-Ghani, M. M. (2016). Traditional medicinal plants of Nigeria: an overview. Agriculture and Biology Journal of North America, 7(5), 220-247.

20. Sukumaran, S., \& Raj, A. D. S. (2010). Medicinal plants of sacred groves in Kanyakumari district Southern Western Ghats, 9(2),294-299.

21. Verma, S., \& Singh, S. P. (2008). Current and future status of herbal medicines. Veterinary world, 1(11), 347.

22. Gan, R. Y., Kuang, L., Xu, X. R., Zhang, Y., Xia, E. Q., Song, F. L., \& Li, H. B. (2010). Screening of natural antioxidants from traditional Chinese medicinal plants associated with treatment of rheumatic disease. Molecules, 15(9), 5988-5997.

23. Zuo, G. Y., Zhang, X. J., Yang, C. X., Han, J., Wang, G. C., \& Bian, Z. Q. (2012). Evaluation of traditional Chinese medicinal plants for anti-MRSA activity with reference to the treatment record of infectious diseases. Molecules, 17(3), 29552967.

24. Patwardhan B, Warude D, Pushpangadan P, Bhatt N. Ayurveda and traditional Chinese medicine: a comparative overview. Evidence-Based Complementary and Alternative Medicine. 2005 Dec 1;2(4):46573.

25. Wolters B. Jarhtausend vor Kolumbus: Indianische kulturpflanzen und Arzneidrogen. Deutsche Apotheker Zeitung. 1992;40:1-0.

26. Moerman DE. Medicinal plants of native America. University of Michigan Museum; 1986.

27. Turrill WB. Plant-life of the Balkan peninsula. 1929.

28. Davis PH. Flora of Turkey and the East Aegean Islands. Vol. 3. Flora of Turkey and the East Aegean Islands. Vol. 3.. 1970.

29. Güner A, Özhatay N, Ekim T, Başer KH. Flora of Turkey and the east Aegean Islands. Supplement. 2000;2:28.

30. Mahomoodally MF. Traditional medicines in Africa: an appraisal of ten potent African medicinal plants. Evidence-Based Complementary and Alternative Medicine. 2013:1-13.

31. Kudi AC, Umoh JU, Eduvie LO, Gefu J. Screening of some Nigerian medicinal plants for antibacterial activity. Journal of Ethnopharmacology. 1999 Nov 1;67(2):2258.

32. Halberstein RA. Medicinal plants: historical and cross-cultural usage patterns. Annals of epidemiology. 2005 Oct 1;15(9):686-99.

33. Masood M, Arshad M, Qureshi R, Sabir S, Amjad MS, Qureshi H, Tahir Z. Picrorhiza kurroa: An ethnopharmacologically important plant species of Himalayan region. Pure and Applied Biology. 2015 Sep 1;4(3):407.

34. Bhattacharjee S, Bhattacharya S, Jana S, Bhagel DS. A review on medicinally important species of Picrorhiza. Intl J Pharm Res Biosci. 2013;2(4):1-6.

35. Sharma R. A Comparative Analytical Study of Different Extracts of katuki (Picrorhiza kurroa). 2020;5(6):122-126.

36. Nadkarni, K.M., Nadkarni, A.K. The Indian Materia Medica. Popular Prakashan, Bombay, India. 1976:953-955.

37. Thakur MK, Chauhan R, Pant KS. Bioresources for productivity enhancement in Kutki, Picrorhiza kurroa Royle ex Benth. 
Intl. J. Bioresour. Stress Manage. 2013 Dec $1 ; 4(4): 482-86$.

38. Sah JN, Varshney VK. Chemical constituents of Picrorhiza genus. American Journal of Essential Oils and Natural Products. 2013;1(2):22-37.

39. Bhandari P, Kumar N, Singh B, Gupta AP, Kaul VK, Ahuja PS. Stability-indicating LC-PDA method for determination of picrosides in hepatoprotective Indian herbal preparations of Picrorhiza kurroa. Chromatographia. 2009 Feb;69(3):221-7.

40. Chopra RN, Chopra IC, Handa KL, Kapur LD. Indigenous drugs of India, UN Dhur and sons Pvt. Ltd., Calcutta. 1958;2.

41. Pandey GS. Bhavaprakasa Nighantoo (Indian Materia Medica). Chaukhamba Sanskrit Sansthan, Varanasi, India. 1979:701.

42. Sultan P, Rasool S, Hassan QP. Picrorhiza kurroa Royle ex Benth. A plant of diverse pharmacological potential. Ann Phytomed. 2017 Jan 1;6(1):63-7.

43. Prakash V, Kumari A, Kaur H, Kumar M, Gupta S, Bala R. Chemical Constituents and Biological Activities of Genus Picrorhiza: An Update. Indian Journal of Pharmaceutical Sciences. 2020 Apr 10;82(4):562-77.

44. Rasool S, Khan MH, Hamid S, Sultan PS, Qazi P, Butt T. An overview and economical importance of few selected endangered medicinal plants grown in Jammu and Kashmir region of India. Ann Phytomed. 2016 Jul 1;5:27-37.

45. Kar A. Pharmaocgnosy and Pharmacobiotechnology (Revised-Expanded Second Edition). New Age International Limted Publishres New Delhi. 2007:196197.

46. Liu XL, You C, Yang YW, Zhang L, Qian ZG. Anatomy and adaptation to environment study of endangered alpine medical plant Neopicrorhiza scrophulariiflora. Zhong yao cai $=$ Zhongyaocai $=$ Journal of Chinese medicinal materials. 2010 Apr 1;33(4):507-10.

47. Coventry BO. Wild flowers of Kashmir. Bishen Singh Mahendra Pal Singh; 1984:89-90.

48. Thakur MK. Effect of preplanting water dip treatments on sprouting and yield attributes of Picrorhiza kurrooa Royle ex Benth. Journal of Tree Sciences. 2015;34(1):69-73.
49. Sharma S, Sharma S, Sharma V, Singh MJ. Conservation of Picrorrhiza kurroa with arbuscular mycorrhizal fungi: An endangered and highly economic medicinal herb of Himalaya. Medicinal PlantsInternational Journal of Phytomedicines and Related Industries. 2020;12(1):33-40.

50. Convention on International Trade in Endangered Species of Wild Fauna and Flora. Fourteenth meeting of the Conference of the Parties The Hague (Netherlands). 2007:1-14.

51. Sharma N, Pathania V, Singh B, Gupta RC. Intraspecific variability of main phytochemical compounds in Picrorhiza kurroa Royle ex Benth. from North Indian higher altitude Himalayas using reversedphase high-performance liquid chromatography. Journal of Medicinal Plants Research. 2012;6(16):3181-7.

52. Thapliyal S, Mahadevan N, Nanjan MJ. Analysis of picroside I and kutkoside in Picrorhiza kurroa and its formulation by HPTLC. International Journal of Research in Pharmaceutical and Biomedical Sciences. 2012;3(1):25-30.

53. Salma U, Kundu S, Gantait S. Phytochemistry and pharmaceutical significance of Picrorhiza kurroa Royle ex Benth. Phytochemistry and pharmacology of medicinal herbs. 2017:26-37.

54. Simons JM, A't Hart B, Ching TR, Van Dijk $\mathrm{H}$, Labadie RP. Metabolic activation of natural phenols into selective oxidative burst agonists by activated human neutrophils. Free Radical Biology and Medicine. 1990 Jan 1;8(3):251-8.

55. Stuppner H, Wagner H. New cucurbitacin glycosides from Picrorhiza kurrooa. Planta medica. 1989 Dec;55(06):559-63.

56. Weinges K, Kloss P, Henkels WD. Natural products from medicinal plants. XVII, picroside II, a new. 1972:173-82.

57. Kumar N, Kumar T, Sharma SK. Phytopharmacological review on genus Picrorhiza. Int J Universal Pharm Bio Sci. 2013;2(4):334-47.

58. Singh AP. Kutkins-A Review of Chemistry and Pharmacology. Ethnobotanical Leaflets. 2004;2004(1):9.

59. Hankey A. CAM modalities can stimulate advances in theoretical biology. EvidenceBased Complementary and Alternative Medicine. 2005 Feb;2(1):5-12. 
60. Lad V. The human constitution. Ayurveda: The Science of Self-Healing. Lotus Press, Wilmot. 1985:26-36.

61. Arya D, Bhatt D, Kumar R, Tewari LM, Kishor K, Joshi GC. Studies on natural resources, trade and conservation of Kutki (Picrorhiza kurroa Royle ex Benth., Scrophulariaceae) from Kumaun Himalaya. Scientific Research and Essays. 2013 Apr 11;8(14):575-80.

62. Bhattacharjee S. a Review on medicinally important species of Picorrhiza. International Journal of Pharmaceutical Research and Bio.2013;2(4):1-6.

63. Singh R, Upadhyay SK, Tuli HS, Singh M, Kumar V, Yadav M, Aggarwal D, Kumar S. Ethnobotany and Herbal Medicine: Some Local Plants with Anticancer Activity. Bulletin of Pure \& Applied SciencesBotany. 2020 Jan 1(1).

64. Verma PC, Basu V, Gupta V, Saxena G, Ur Rahman L. Pharmacology and chemistry of a potent hepatoprotective compound Picroliv isolated from the roots and rhizomes of Picrorhiza kurroa royle ex benth.(kutki). Current pharmaceutical biotechnology. 2009 Sep 1;10(6):641-9.

65. Muddgal D. Dravyagun Vijnana. Ayurvedic hindi pustak bhandar. 2nd edition 2019.

66. Sharma PV. Dravyagun Vigyan. Chaukambha Bharti Academy, Varanasi. 2019.

67. Shilpa P, Upadhyaya A. PHARMACOGNOSTICAL

\begin{tabular}{llrr} 
EVALUATION & OF & \multicolumn{2}{r}{ KATUKA } \\
(PICRORHIZA & KURROA & ROYLE & EX \\
BENTH.). International & Journal of \\
Ayurveda & and & Pharma & Research. \\
$2018 ; 6(7): 65-69$. & & &
\end{tabular}

68. Rana RT, Mahto RR. Ayurveda: A world where diabetes can do no harm. 201;3(1):15.

69. Prabhu K, Rao MR, Akhil K, Jayanti ST, Soniya S, Kalaivanan J, Ravi A, Dinakar S. The GC-MS study of one ayurvedic formulation tiktaka ghrita. Drug Invention Today. 2020 May 15;14(5).

70. Joglekar N, Datye A, Pawaskar M. A case study of Plantar Psoriasis. Journal of Ayurveda and Integrated Medical Sciences| Jan-Feb. 2020;5(1):259.

71. Samal J. Ayurvedic preparations for the management of Iron Deficiency Anemia: A systematic review. Ayu. 2016 Jul;37(34):163.
72. Rahman AH, Alam MS, Khan SK, Ahmed F, Islam AK, Rahman MM. Taxonomic studies on the family Asteraceae (Compositae) of the Rajshahi division. Research Journal of Agriculture and Biological Sciences. 2008;4(2):134-40.

73. Phondani PC, Maikhuri RK, Rawat LS, Farooquee NA, Kala CP, Vishvakarma SR, Rao KS, Saxena KG. Ethnobotanical uses of plants among the Bhotiya tribal communities of Niti Valley in Central Himalaya, India. 2010;8:233-244.

74. Guleria V, Vasishth A. Ethnobotanical uses of wild medicinal plants by Guddi and Gujjar tribes of Himachal Pradesh. Ethnobotanical Leaflets. 2009;2009(9):8.

75. Kumar N, Choyal R. Traditional use of some plants of Hamirpur district of Himachal Pradesh for the treatment of jaundice, hepatitis and other liver disorders. International Journal of Theoretical \& Applied Sciences. 2012;4(2):201-205.

76. Sharma V, Singh B, Gupta RC, Dhaliwal HS. Comprehensive ethno-botanical survey and cytomorphological status of some important medicinal plants from Himachal Pradesh-A north Indian state. World J. Pharm. Res. 2014 Sep 18;3(10):681-712.

77. Dutt B, Nath D, Chauhan NS, Sharma KR, Sharma SS. Ethno-medicinal plant resources of tribal Pangi Valley in district Chamba, Himachal Pradesh, India. Int. J. Bio-Res. Stress Manag. 2014 Sep 1;5:416-21.

78. Lone FA, Lone S, Aziz MA, Malla FA. Ethnobotanical studies in the tribal areas of district Kupwara, Kashmir, India. Intl J Pharma BioScie. 2012;3(4):399-411.

79. Kapahi BK, Srivastava TN, Sarin YK. Traditional medicinal plants of Gurez (Kashmir)-an ethnobotanical study. Ancient science of life. 1993 Jul;13(1-2):119.

80. Sharma V, Sharma BL, Bharati KA. Ethnobotanical Notes on Alpine Medicinal Herbs of Kedarnath Range of Garhwal Himalayas.

81. Tamang M, Pal K, Rai SK, Kalam A, Ahmad SR. Ethnobotanical survey of threatened medicinal plants of West Sikkim. 2017;2(6): 116-125.

82. Bantawa P, Rai R. Studies on ethnomedicinal plants used by traditional practitioners, Jhankri, Bijuwa and Phedangma in Darjeeling Himalaya. 2009;8(5):537-541. 
83. Chhetri DR. Medicinal plants used as antipyretic agents by the traditional healers of Darjeeling Himalayas.2004;3(3):271-275.

84. Negi VS, Maikhuri RK, Vashishtha DP. Traditional healthcare practices among the villages of Rawain valley, Uttarkashi, Uttarakhand, India. 2011;10(3):533-537.

85. Ghildiyal JC, Sadana G, Uniyal KM, Bebni D, Bebni P. Ethno-medicinal uses of plants to cure skin disease in Garhwal Himalaya. 2008;3:55-62.

86. Idrisi MS, Badola HK, Singh R. Indigenous knowledge and medicinal use of plants by local communities in Rangit Valley, South Sikkim, India. NeBIO. 2010;1(2):34-45.

87. Bharti KA, Sharma BL. Studies on Ethnoveterinary uses of Plant Resources of Sikkim. Indian Forester. 2009 May 1;135(5):691.

88. Semwal DP, Saradhi PP, Kala CP, Sajwan BS. Medicinal plants used by local Vaidyas in Ukhimath block, Uttarakhand. 2010;9(3):480-485.

89. Singh RK, Negi AK. Traditional knowledge and use of medicinal plants: a case study from Joshimath block of Chamoli Uttarakhand. Technology. 2019:122-127.

90. Sekar KC, Rawat B. Diversity, utilization and conservation of ethno-medicinal plants in Devikund-A high altitude, sacred wetland of Indian Himalaya. Med. Plants. 2011;3(2):105-12.

91. Bhardwaj M, Bharadwaj L, Trigunayat K, Trigunayat MM. Insecticidal and wormicidal plants from Aravalli hill range of India. Journal of ethnopharmacology. 2011 Jun 14;136(1):103-10.

92. Nand K, Naithani S. Ethnobotanical uses of wild medicinal plants by the local community in the Asi Ganga Sub-basin, Western Himalaya. J Complement Med Res. 2018 Jan 1;9(1):34-46.

93. Chhetri DR, Parajuli P, Subba GC. Antidiabetic plants used by Sikkim and Darjeeling Himalayan tribes, India. Journal of Ethnopharmacology. 2005 Jun 3;99(2):199-202.

94. Maity D, Pradhan N, Chauhan AS. Folk uses of some medicinal plants from North Sikkim. 2004;3(1):6-71.

95. Pradhan BK, Badola HK. Ethnomedicinal plant use by Lepcha tribe of Dzongu valley, bordering Khangchendzonga Biosphere Reserve, in north Sikkim, India. Journal of
Ethnobiology and Ethnomedicine. 2008 Dec;4(1):1-8.

96. Ballabh B, Chaurasia OP. Medicinal plants of cold desert Ladakh used in the treatment of stomach disorders. 2009;8(2):185-190.

97. Bhattarai NK. Traditional phytotherapy among the Sherpas of Helambu, central Nepal. Journal of Ethnopharmacology. 1989 Nov 1;27(1-2):45-54.

98. Badola HK, Pradhan BK. Plants used in healthcare practices by limboo tribe in south-west of khangchendzonga biosphere reserve, Sikkim, India. 2013;12(3):355-369.

99. Sharma PK, Chauhan NS, Lal B. Observations on the traditional phytotherapy among the inhabitants of Parvati valley in western Himalaya, India. Journal of Ethnopharmacology. 2004 Jun 1;92(23):167-76.

100. Ratha KK, Arya JC, Joshi GC, Rao MM. Contribution of Regional Ethno Medicinal Flora of Tungnath-Chopta Region, Uttarakhand to Ayurveda. 2018:110.

101. Mukherjee D. Current status, distribution and ethno-medicinal values of medicinal plant in hilly regions of Darjeeling district of West Bengal. Journal of Crop and Weed. 2009;5(1):316-20.

102. Kamboj VP. Herbal medicine. Current science. 2000 Jan 10;78(1):35-9.

103. Joharchi MR, Amiri MS. Taxonomic evaluation of misidentification of crude herbal drugs marketed in Iran. Avicenna journal of phytomedicine. 2012;2(2):105.

104. Adewunmi CO, Ojewole JA. Safety of traditional medicines, complementary and alternative medicines in Africa. African journal of traditional, complementary and alternative medicines. 2004;1(1):1-3.

105. Song J, Yao H, Li Y, Li X, Lin Y, Liu C, Han J, Xie C, Chen S. Authentication of the family Polygonaceae in Chinese pharmacopoeia by DNA barcoding technique. Journal of Ethnopharmacology. 2009 Jul 30;124(3):434-9.

106. Begum SN, Ravikumar K, Ved DK. 'Asoka'-an important medicinal plant, its market scenario and conservation measures in India. Current Science. 2014 Jul 10;107(1):26-8.

107. Mangal AK, Rath C, Tewari D, Dutta S, Srikanth N, Dhiman KS. Microscopical and preliminary physicochemical studies of two important endangered Ayurvedic medicinal 
plants Kutki and Trayamana to establish their identity. J. Drug Res. Ayurvedic Sci. 2017;2:18-22.

108. Kapahi BK, Srivastava TN, Sarin YK. Description of Picrorhiza kurroa, a source of the Ayurvedic drug Kutaki. International journal of pharmacognosy. 1993 Jan $1 ; 31(3): 217-22$.

109. More DB, Giradkar PS. Herbal Drug Adulteration: A Hindrance to the Development of Ayurveda Medicine.

110. Phillipson JD, Anderson LA. Ethnopharmacology and western medicine. Journal of ethnopharmacology. 1989 Feb 1;25(1):61-72.

111. Usman MR, Surekha Y, Chhaya G, Devendra S. Preliminary screening and antimicrobial activity of Picrorhiza kurroa royle ethanolic extracts. Int J Pharm Sci Rev Res. 2012;14:73-6.

112. Sharma SK, Kumar N. Antimicrobial screening of Picrorhiza kurroa Royle ex Benth rhizome. Int J Curr Pharm Rev Res. 2012;3:60-5.

113. Sehgal R, Chauhan A, Gilhotra UK, Gilhotra A. In-vitro and in-vivo evaluation of antiasthmatic activity of Picrorhiza kurroa plant. International Journal of Pharmaceutical Sciences and Research. 2013 Sep 1;4(9):3440.

114. Rajeshkumar NV, Kuttan R. Protective effect of Picroliv, the active constituent of Picrorhiza kurroa, against chemical carcinogenesis in mice. Teratogenesis, carcinogenesis, and mutagenesis. 2001;21(4):303-13.
115. Kalaivani T, Rajasekaran C, Mathew L. In vitro free radical scavenging potential of Picrorhiza kurroa. Journal of Pharmacy Research. 2010 Apr;3(4):849-54.

116. Zaveri M, Patel P, Dhru B, Patel S. Screening of in-vitro anti-mutagenic activity of selected plants. Am J Pharmtech Res. 2011;1:232-43.

117. Hussain A, Shadma W, Maksood A, Ansari SH. Protective effects of Picrorhiza kurroa on cyclophosphamide-induced immunosuppression in mice. Pharmacognosy research. 2013 Jan;5(1):30.

118. Kumar R, Gupta YK, Singh S, Raj A. Anti-inflammatory effect of Picrorhiza kurroa in experimental models of inflammation. Planta medica. 2016 Nov;82(16):1403-9.

119. Shetty SN, Mengi S, Vaidya R, Vaidya AD. A study of standardized extracts of Picrorhiza kurroa Royle ex Benth in experimental nonalcoholic fatty liver disease. Journal of Ayurveda and integrative medicine. $2010 \mathrm{Jul} ; 1(3): 203$.

120. Husain GM, Singh PN, Kumar V. Antidiabetic activity of standardized extract of Picrorhiza kurroa in rat model of NIDDM. Drug discoveries \& therapeutics. 2009;3(3):88-92.

How to cite this article: Kumari I, Kaurav H, Chaudhary G. Ethnobotanical significance of picrorhiza kurroa (kutki), a threatened species. International Journal of Research and Review. 2021; 8(4): 363-375. DOI: https://doi.org/ 10.52403/ijrr.20210443 